University of Nebraska - Lincoln

DigitalCommons@University of Nebraska - Lincoln

\title{
Superambient Heat Capacities of Synthetic Stibnite, Berthierite, and Chalcostibite: Revised Thermodynamic Properties and Implications for Phase Equilibria
}

\author{
Robert R. Seal II \\ U.S. Geological Survey, 954 National Center, Reston, Virginia 20192, USA, rseal@usgs.gov \\ Richard A. Robie \\ USGS
}

Paul B. Barton Jr.

USGS

Bruce Hemingway

USGS

Follow this and additional works at: https://digitalcommons.unl.edu/usgsstaffpub

Part of the Earth Sciences Commons

Seal, Robert R. II; Robie, Richard A.; Barton, Paul B. Jr.; and Hemingway, Bruce, "Superambient Heat Capacities of Synthetic Stibnite, Berthierite, and Chalcostibite: Revised Thermodynamic Properties and Implications for Phase Equilibria" (1992). USGS Staff -- Published Research. 341.

https://digitalcommons.unl.edu/usgsstaffpub/341

This Article is brought to you for free and open access by the US Geological Survey at DigitalCommons@University of Nebraska - Lincoln. It has been accepted for inclusion in USGS Staff -- Published Research by an authorized administrator of DigitalCommons@University of Nebraska - Lincoln. 


\title{
SUPERAMBIENT HEAT CAPACITIES OF SYNTHETIC STIBNITE, BERTHIERITE, AND CHALCOSTIBITE: REVISED THERMODYNAMIC PROPERTIES AND IMPLICATIONS FOR PHASE EQUILIBRIA
}

\author{
ROBERT R. SEAL II, \\ U. S. Geological Survey, 954 National Center, Reston, Virginia 22092
}

\author{
Richard A. Robie, Paul B. Barton, Jr., and Bruce S. Hemingway \\ U. S. Geological Survey, 959 National Center, Reston, Virginia 22092
}

\section{Introduction}

Stibnite $\left(\mathrm{Sb}_{2} \mathrm{~S}_{3}\right)$, berthierite $\left(\mathrm{FeSb}_{2} \mathrm{~S}_{4}\right)$, and chalcostibite $\left(\mathrm{CuSbS}_{2}\right)$ are important antimony-bearing minerals. Stibnite is the main ore mineral of antimony and occurs as an important accessory in many epigenetic ore deposits, especially in later stages of deposition or in peripheral facies of mineralization. Berthierite is a common accessory mineral in antimony deposits. Its occurrence, particularly in gold-antimony deposits, has received considerable scientific attention. Furthermore, stibnite, berthierite, and chalcostibite represent important reference phases for understanding phase equilibria in more complex systems, such as those containing tetrahedrite-tennantite solid solutions.

Barton (1971) emphasized the uncertainties in the low-temperature $(<573 \mathrm{~K})$ phase equilibria in the system $\mathrm{Fe}-\mathrm{Sb}-\mathrm{S}$, particularly for reactions involving berthierite and gudmundite ( FeSbS), which he attributed to the difficulty in extrapolating high-temperature phase equilibria data to lower temperatures. Thus, the application of high-temperature $(>573 \mathrm{~K}$ ) phase equilibrium studies to the study of ore deposits has been hampered by the difficulty in accurately extrapolating the high-temperature data to lower, more geologically relevant temperatures. Likewise, the extrapolation of low-temperature $(\leq 298 \mathrm{~K})$ enthalpy and heat capacity data to higher, more geologically pertinent temperatures has been hindered by an incomplete understanding of the thermodynamic properties of these minerals. Heat capacities measured by differential scanning calorimetry provide a means of bridging the gap between the low-temperature calorimetric studies and the high-temperature phase equilibrium studies. This study presents new heat capacity data for synthetic stibnite, berthierite, and chalcostibite from 340 to $760 \mathrm{~K}$, which are used to revise the thermodynamic properties of these minerals. The new thermodynamic values for these minerals are used to improve our understanding of phase relations in the system $\mathrm{Fe}-\mathrm{Sb}$-S.

\section{Materials and Experimental Methods}

Stibnite, berthierite, and chalcostibite were synthesized from antimony metal (ASARCO, 99.999+\%, lot ZH-2262), iron wire (Materials Research Corp.,
VP grade, lot 2612201), copper wire (Baker and Adamson, 99.90\%, lot J337), and native sulfur (ASARCO, 99.999+\%, lot 102). The iron wire was reduced in a stream of hydrogen gas at $873 \mathrm{~K}$ for $1 \mathrm{~h}$. The copper wire was cleaned in acetone prior to use. For each phase, reagents were weighed in stoichiometric proportions with total masses between 1 and $3 \mathrm{~g}$ and sealed in evacuated silica tubes. The tubes were placed in a furnace at $1,023 \mathrm{~K}$ and reacted for $1 \mathrm{~h}$ and then quenched. The tubes were opened; the contents were ground under acetone, air-dried, and then resealed in evacuated silica tubes. The samples were annealed for two weeks at $748 \pm 10 \mathrm{~K}$ and then quenched in ice water. The berthierite sample underwent two additional grinding and annealing cycles.

The samples were characterized by reflected light microscopy, powder X-ray diffraction, and electron microprobe analysis and were found to be stoichiometric and homogeneous within the analytic precision and $>99$ percent pure inasmuch as no impurity phases were detected. Cell parameters were determined using powder X-ray diffraction data from the synthetic material. Barium fluoride was used as an internal standard with stibnite; silicon (NBS-640) was used with berthierite and chalcostibite. The results of the electron microprobe and X-ray diffraction studies are presented in Table 1.

Heat capacities were measured from 340 to $760 \mathrm{~K}$ with a Perkin-Elmer DSC-2 differential scanning calorimeter following the procedures described by Hemingway et al. (1981). The calorimetric sample weights were $65.88,58.72$, and $58.76 \mathrm{mg}$ for stibnite, chalcostibite, and berthierite, respectively. Samples were sealed in aluminum pans. Reweighing of the samples after the heat capacity measurements were completed indicated that desulfidation and/or oxidation were not a problem. Reaction between the samples and their aluminum pans also was not a problem; the examination of the pans after all measurements were made revealed clean, untarnished inner surfaces.

\section{Results}

The heat capacities $\left(\mathrm{C}_{\mathrm{p}}^{\circ}\right)$ measured by the present study from 340 to $760 \mathrm{~K}$ for stibnite, berthierite, 
TABLE 1. Electron Microprobe and X-Ray Diffraction Data for Synthetic Stibnite, Berthierite, and Chalcostibite

\begin{tabular}{|c|c|c|c|}
\hline & Stibnite & Berthierite & Chalcostibite \\
\hline \multicolumn{4}{|c|}{ Wt percent } \\
\hline $\mathrm{Sb}$ & $72.29 \pm 0.41$ & $57.50 \pm 0.61$ & $49.24 \pm 0.35$ \\
\hline $\mathrm{Fe}$ & $0.01 \pm 0.02$ & $13.07 \pm 0.23$ & $0.01 \pm 0.01$ \\
\hline $\mathrm{Cu}$ & $0.02 \pm 0.03$ & $0.03 \pm 0.03$ & $25.57 \pm 0.21$ \\
\hline$S$ & $28.62 \pm 0.33$ & $30.33 \pm 0.39$ & $26.36 \pm 0.15$ \\
\hline Total & $100.94 \pm 0.68$ & $100.93 \pm 1.13$ & $101.18 \pm 0.40$ \\
\hline$n$ & 18 & 15 & 24 \\
\hline \multicolumn{4}{|c|}{ Formula normalized to sulfur atoms } \\
\hline $\mathrm{Sb}$ & $2.00 \pm 0.02$ & $2.00 \pm 0.02$ & $0.98 \pm 0.01$ \\
\hline $\mathrm{Fe}$ & & $0.99 \pm 0.01$ & \\
\hline $\mathrm{Cu}$ & & & $0.98 \pm 0.01$ \\
\hline$S$ & 3.00 & 4.00 & 2.00 \\
\hline \multicolumn{4}{|c|}{ Cell parameters $(\AA)$} \\
\hline a & 11.228 & 11.461 & 6.015 \\
\hline b & 11.309 & 14.173 & 14.540 \\
\hline c. & 3.834 & 3.771 & 3.802 \\
\hline
\end{tabular}

All uncertainties are expressed as $2 \sigma$; uncertainty in cell parameters is estimated at $\pm 0.001 \AA$; published cell parameters: stibnite $(\mathbf{P b n m}), \mathrm{a}=11.229, \mathrm{~b}=11.311, \mathrm{c}=3.836 \AA$ (Bayliss and Nowacki, 1972); berthierite (Pnam), $\mathrm{a}=11.44, \mathrm{~b}=14.12, \mathrm{c}=3.76 \AA$ (Buerger and Hahn, 1955); chalcostibite (Pnam), $\mathrm{a}=6.00, \mathrm{~b}=$ 14.45, $\mathrm{c}=3.78 \AA$ (Hofman, 1933)

and chalcostibite are presented in Table 2 and Figure 1. None of the phases displayed any anomalous behavior. The measured heat capacities were fit by least squares to an equation of the form suggested by Haas and Fisher (1976). Terms that did not improve the precision of the regressions were discarded. The equation for stibnite was constrained to join smoothly the low-temperature $\mathrm{C}_{\mathrm{p}}^{\circ}$ data of Romanovskii and Tarasov (1960) and King and Weller (1962). The equation for berthierite was constrained to join smoothly the low-temperature $\mathrm{C}_{\mathrm{p}}^{\circ}$ data presented by Dzhabbarov (1985). The heat capacity data for chalcostibite were graphically extrapolated down to 298.15 K. For stibnite, berthierite, and chalcostibite, the heat capacity data were graphically extrapolated up to the decomposition temperatures of the phases (829, 836, and $826 \mathrm{~K}$, respectively).

For stibnite, berthierite, and chalcostibite, the resulting equations $\left(\mathrm{J} \cdot\right.$ mole $^{-1} \cdot \mathrm{K}^{-1} ; \mathrm{T}$ in $\mathrm{K}$; and the ranges for which they are valid) are $\mathrm{C}_{\mathrm{p}}^{\circ}$ (stibnite) $=$ $166.1-0.0031 \mathrm{~T}+654,000 \mathrm{~T}^{-2}-911 \mathrm{~T}^{-0.5}(298$ $829 \mathrm{~K}) ; \mathrm{C}_{\mathrm{p}}^{\circ}$ (berthierite) $=10.0+0.0793 \mathrm{~T}-$ $6,416,000 \mathrm{~T}^{-2}+3,691 \mathrm{~T}^{-0.5}(298-836 \mathrm{~K})$; and $\mathrm{C}_{\mathrm{p}}^{\circ}$ $($ chalcostibite $)=88.1+0.0404 \mathrm{~T}(298-826 \mathrm{~K})$, which describe the data with an average absolute deviation of $0.3,0.5$, and 0.3 percent, respectively.

The heat content $\left(\mathbf{H}_{\mathrm{T}}^{\circ}-\mathbf{H}_{298}^{\circ}\right)$ data for stibnite from Johnson et al. (1981) are within the analytic uncertainty of the integrated values from the present study below $700 \mathrm{~K}$. However, the heat content data of Johnson et al. (1981) are greater than those of the present study by up to $1.45 \mathrm{~kJ} \cdot \mathrm{mole}^{-1}(2.2 \%)$ at 823 $\mathrm{K}$, the melting point of stibnite. For the drop calorimetry data, eutectic melting of a slightly nonstoichiometric sample along the $\mathrm{Sb}_{2} \mathrm{~S}_{3}-\mathrm{S}$ join $(769 \mathrm{~K})$ or the $\mathrm{Sb}_{2} \mathrm{~S}_{3}$-Sb join $(791 \mathrm{~K}$ ) may be responsible for some of this deviation but probably cannot account for all of this behavior. Unfortunately, the synthesis and characterization of the sample of Johnson et al. (1981) is insufficiently documented to assess this possibility. Thus, the differential scanning calorimetry data of the present study is preferred for subsequent calculations.

\section{Revised Thermodynamic Properties}

\section{Stibnite}

Numerous workers have investigated the phase equilibria and thermodynamic properties of stibnite. Barton (1971) conducted a phase equilibrium study of the system $\mathrm{Fe}-\mathrm{Sb}-\mathrm{S}$, made estimates of $\Delta_{f} \mathrm{G}^{\circ}$ values, and summarized experimental work prior to that time. Mills (1974) compiled and evaluated the thermodynamic data for $\mathrm{Sb}_{2} \mathrm{~S}_{3}$. More recently, Johnson et al. (1981) determined a $\Delta_{f} \mathrm{H}_{298}^{\circ}$ value by fluorine combustion calorimetry. They also measured superambient heat capacities by drop calorimetry. Bryndzia and Kleppa (1988a) determined a $\Delta_{f} \mathrm{H}_{298}^{\circ}$ for stibnite by high-temperature reaction calorimetry. Despite the abundance of data, considerable uncertainty remains regarding the enthalpy of formation of stibnite (Table 3).

The $\mathrm{C}_{\mathrm{p}}^{\circ}$ expression from the present study was combined with the $S_{298}^{\circ}$ value for stibnite (Mills, 1974), which is the mean of the values of Romanovskii and Tarasov (1960) and King and Weller (1962), and high-temperature experimental data for the sulfidation of native antimony (Schenck and von der Forst, 1939) to calculate $\Delta_{f} \mathrm{G}_{298}^{\circ}, \Delta_{f} \mathrm{H}_{298}^{\circ}$, and an expression for $\Delta_{f} \mathrm{G}^{\circ}$ as a function of temperature for stibnite. Following Barton (1971), the present study accepted the $673 \mathrm{~K} \log f_{\mathrm{s}_{2}}$ value of -9.24 (Schenck and von der Forst, 1939) for the reaction:

$$
2 \mathrm{Sb}+3 / 2 \mathrm{~S}_{2}=\mathrm{Sb}_{2} \mathrm{~S}_{3} .
$$

The comparison of the calculated curve for this reaction with the independent experimental determination of the sulfur fugacity associated with reaction 1 of Barton (1971) by the pyrrhotite indicator method confirms the validity of the resulting $\Delta_{f} \mathrm{G}^{\circ}$ values (Fig. 2). The expression for $\Delta_{f} \mathrm{G}^{\circ}$ as a function of temperature from the present study is identical to the expression of Barton (1971) within the experimental uncertainty. The thermodynamic properties of stibnite are summarized in Table 4. 
TABLE 2. Experimental Molar Heat Capacities of Stibnite, Berthierite, and Chalcostibite

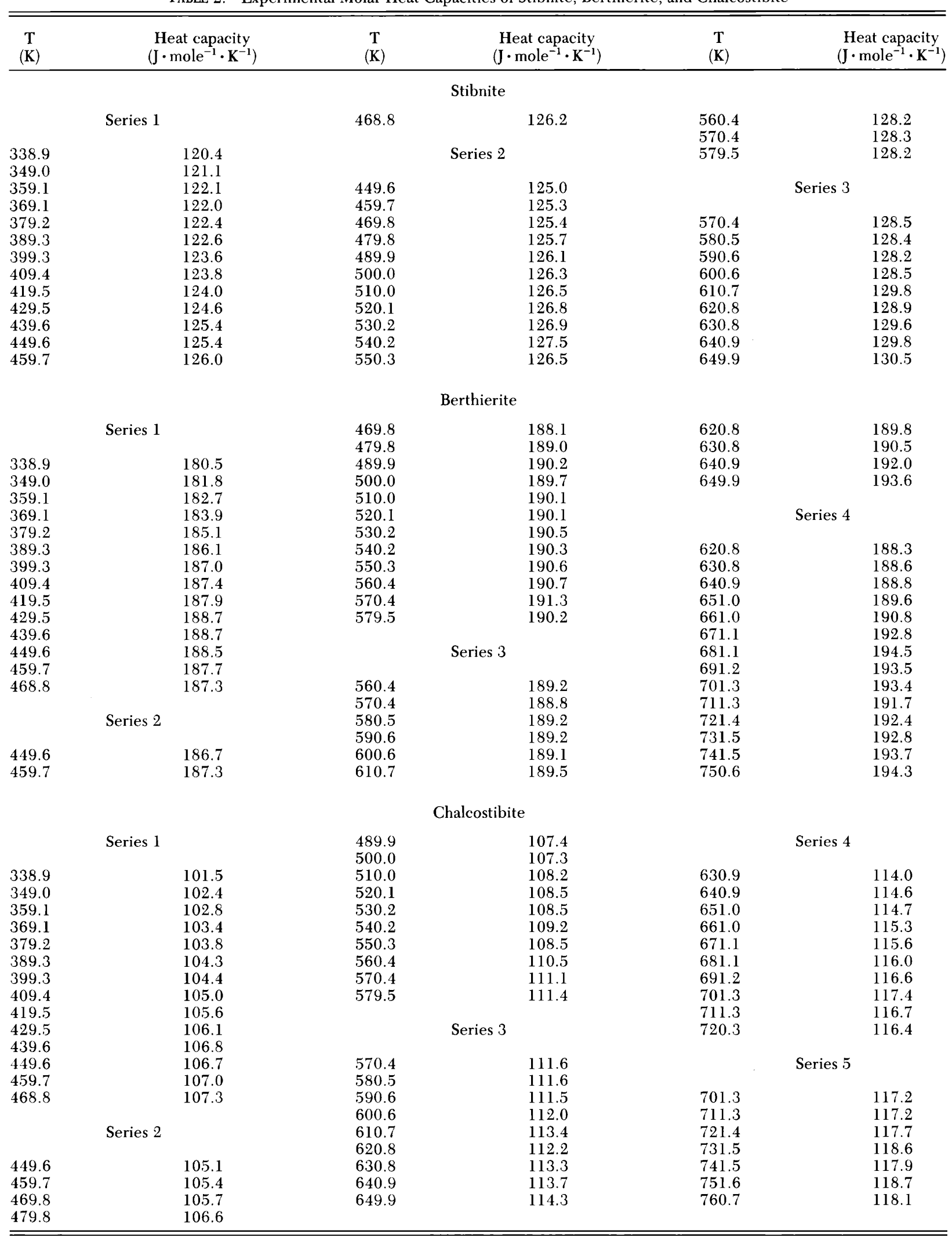

Molar masses: stibnite, $339.68 \mathrm{~g}$; berthierite, $427.587 \mathrm{~g}$; chalcostibite, $249.416 \mathrm{~g}$ 


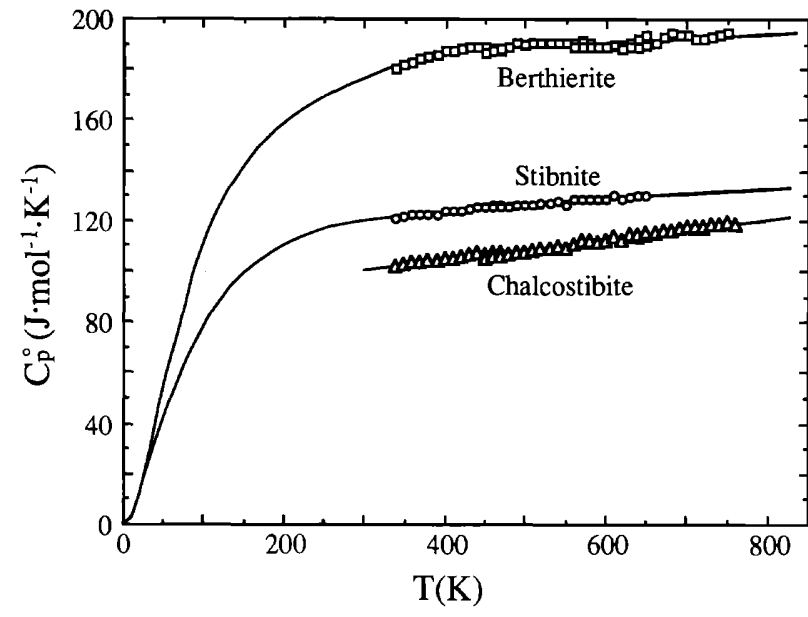

F1G. 1. Experimental superambient heat capacities for stibnite, berthierite, and chalcostibite. Solid curves represent smoothed values for heat capacities. Curves above $300 \mathrm{~K}$ are from the present study. The curve for stibnite below $300 \mathrm{~K}$ is from Romanovskii and Tarasov (1960) and King and Weller (1962). The curve for berthierite below $300 \mathrm{~K}$ is from Dzhabbarov (1985).

\section{Berthierite}

Phase equilibria involving berthierite have been studied by Barton (1971), Bortnikov et al. (1978), and Nekrasov and Konyushok (1982). All three studies used the pyrrhotite indicator technique (Toulmin and Barton, 1964) to measure sulfur fugacities in equilibrium with univariant assemblages. The first two studies were conducted under anhydrous conditions, whereas the third was under hydrothermal conditions. In addition, Dzhabbarov (1985) measured low-temperature (6-300 K) heat capacities for berthierite and presented an $S_{298}^{\circ}$ value for this mineral.

The present study combined the high-temperature phase equilibrium studies of Barton (1971), Bortnikov et al. (1978), and Nekrasov and Konyushok (1982), the $S_{298}^{\circ}$ of berthierite (Dzhabbarov, 1985),

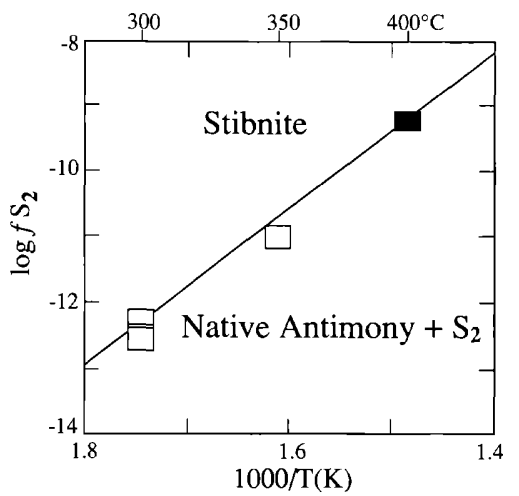

FIG. 2. Temperature- $f_{\mathrm{S}_{2}}$ diagram for reaction 1 . The line represents the calculated curve from the present study. The filled square is the value from Schenck and von der Forst (1939), which was used to generate the thermodynamic parameters used in the present study. Open squares are from Barton (1971). The uncertainty in the temperature and $\log f_{\mathrm{S}_{2}}$ values of Barton (1971) is $\pm 5^{\circ} \mathrm{C}$ and $\pm 0.35 \log f_{\mathrm{s}_{2}}$ units, respectively.

and the $\mathrm{C}_{\mathrm{p}}^{\circ}$ expression from the present study to calculate $\Delta_{f} \mathrm{G}_{298}^{\circ}, \Delta_{f} \mathrm{H}_{298}^{\circ}$, and an expression for $\Delta_{f} \mathrm{G}^{\circ}$ as a function of temperature for berthierite. Specifically, the two berthierite-bearing reactions considered were:

$$
\mathrm{FeSb}_{2} \mathrm{~S}_{4}+1 / 2 \mathrm{~S}_{2}=\mathrm{FeS}_{2}+\mathrm{Sb}_{2} \mathrm{~S}_{3}
$$

where it intersects the pyrite-pyrrhotite buffer (Barton, 1971) and

$$
\mathrm{FeS}+2 \mathrm{Sb}+3 / 2 \mathrm{~S}_{2}=\mathrm{FeSb}_{2} \mathrm{~S}_{4}
$$

within the pyrrhotite field (Barton, 1971; Bortnikov et al., 1978; Nekrasov and Konyushok, 1982). Barton (1971) reported an equilibrium temperature of $805 \pm 5 \mathrm{~K}\left(532^{\circ} \mathrm{C}\right)$ for the five-phase invariant assemblage berthierite + pyrite + stibnite + pyrrhotite + vapor. At this temperature, the pyrite-pyrrhotite buffer defines a $\log f_{\mathrm{S}_{2}}$ of -3.58 (Toulmin and Barton, 1964) for reaction 2 (Fig. 4). Using the free energy data for pyrite from Barton and Skinner (1979), a

\begin{tabular}{|c|c|c|}
\hline Source & $\begin{array}{c}\Delta_{f} \mathrm{H}_{298}^{\circ} \\
\left(\mathrm{kJ} \cdot \mathrm{mole}^{-1}\right)\end{array}$ & Method \\
\hline Pelabon (1902) & $-152.72^{1}$ & $\mathrm{H}_{2} \mathrm{~S} / \mathrm{H}_{2}$ mixing experiments \\
\hline Jellinek and Zakowski (1925) & $-154.81^{1}$ & $\mathrm{H}_{2} \mathrm{~S} / \mathrm{H}_{2}$ mixing experiments \\
\hline Britzke and Kapustinskii (1930) & $-150.02^{1}$ & $\mathrm{H}_{2} \mathrm{~S} / \mathrm{H}_{2}$ mixing experiments \\
\hline Kelley (1937) & -162.34 & Recalculated from published data \\
\hline Sudo (1952) & $-205.02^{1}$ & $\mathrm{H}_{2} \mathrm{~S} / \mathrm{H}_{2}$ mixing experiments \\
\hline Barton (1971) & -151.04 & Calculated $^{2}$ \\
\hline Johnson et al. (1981) & -141.80 & Fluorine combustion calorimetry \\
\hline Bryndzia and Kleppa (1988a) & -129.72 & Reaction drop calorimetry \\
\hline This study & -151.35 & Calculated $^{2}$ \\
\hline
\end{tabular}

TABLE 3. Comparison of $\Delta_{f} \mathrm{H}_{298}^{\circ}$ Values for Stibnite Relative to Sb Metal and Crystalline $\mathrm{S}$

${ }^{1}$ Third law evaluation by Mills (1974) of published gas-mixing experimental data

${ }^{2}$ Calculated by the present study based on $\Delta_{f} G_{298}^{\circ}$ value 
$\Delta_{f} \mathrm{G}_{805}^{\circ}$ for stibnite calculated from the present study, and the $\log f_{\mathrm{S}_{2}}$ value for reaction 2 , a $\Delta_{f} \mathrm{G}_{805}^{\circ}$ of $-259.19 \mathrm{~kJ} \cdot$ mole $^{-1}$ can be calculated for berthierite. Tight constraints on the equilibrium sulfur fugacity $\left(\log f_{\mathrm{s}_{2}}=-12.46\right)$ associated with reaction (3) at $573 \mathrm{~K}\left(300^{\circ} \mathrm{C}\right)$ can be obtained from the work of Nekrasov and Konyushok (1982) (Fig. 3). This value can be used to calculate a $\Delta_{f} \mathrm{G}_{573}^{\circ}$ for berthierite $\left(-327.21 \mathrm{~kJ} \cdot\right.$ mole $\left.^{-1}\right)$ using the free energy and activity-composition data for pyrrhotite of Toulmin and Barton (1964). A $\Delta_{f} G_{298}^{\circ}$ value that produced the best fit to the $\Delta_{f} \mathrm{G}_{573}^{\circ}$ and $\Delta_{f} \mathrm{G}_{805}^{\circ}$ values was calculated using the $C_{p}^{\circ}$ expression and $S_{298}^{\circ}$ value from Table 4 . The resulting $\Delta_{f} \mathrm{G}^{\circ}$ values were used to calculate the position of reaction 3 in terms of temperature and sulfur fugacity. A comparison of the calculated curve with the experimental data (Fig. 3) verifies the validity of the calculated $\Delta_{f} \mathrm{G}^{\circ}$ values. The thermodynamic properties of berthierite are summarized in Table 4.

\section{Chalcostibite}

The present study combined the $\Delta_{f} \mathrm{G}_{673}^{\circ}$ value from Craig and Lees (1972), based on the gas-mixing experiments of Schenck et al. (1939), the $\mathrm{C}_{\mathrm{p}}^{\circ}$ expression for chalcostibite from this study, and an estimate for the $S_{298}^{\circ}$ of chalcostibite to calculate $\Delta_{f} \mathrm{G}_{298}^{\circ}=$ $-132.86 \mathrm{~kJ} \cdot \mathrm{mole}^{-1}$, and $\Delta_{f} \mathbf{H}_{298}^{\circ}=-130.79$ $\mathrm{kJ} \cdot \mathrm{mole}^{-1}$ for chalcostibite. The estimate for the $\mathrm{S}_{298}^{\circ}$ of chalcostibite $\left(149.2 \mathrm{~J} \cdot \mathrm{mole}^{-1} \cdot \mathrm{K}^{-1}\right)$ is based on the sum of the $S_{298}^{\circ}$ values for the component sulfides $\left(\mathrm{S}_{298}^{\circ}\left(\mathrm{CuSbS}_{2}\right)=1 / 2 \mathrm{~S}_{298}^{\circ}\left(\mathrm{Cu}_{2} \mathrm{~S}\right.\right.$; Grønvold and Westrum, 1987) $+1 / 2 S_{298}^{\circ}\left(\mathrm{Sb}_{2} \mathrm{~S}_{3}\right.$; Mills, 1974)). Seal et al. (1990) noted that the sum of the component $\mathrm{S}_{298}^{\circ}$ values for smithite $\left(\mathrm{AgAsS}_{2}\right)$, proustite $\left(\mathrm{Ag}_{3} \mathrm{AsS}_{3}\right)$, and chalcopyrite $\left(\mathrm{CuFeS}_{2}\right)$ are within 2.5 percent of the $\mathrm{S}_{298}^{\circ}$ values of the compounds (Robie et al., 1985; Gurevich et al., 1989). Likewise, the sum of the $S_{298}^{\circ}$ values for the sulfide components of berthierite $\left(S_{298}^{\circ}\left(\mathrm{FeS}\right.\right.$; Robie et al., 1979) $+\mathrm{S}_{298}^{\circ}$ $\left(\mathrm{Sb}_{2} \mathrm{~S}_{3} ;\right.$ Mills, 1974$\left.)=242.3 \mathrm{~J} \cdot \mathrm{mole}^{-1} \cdot \mathrm{K}^{-1}\right)$ is within 1.1 percent of the $\mathrm{S}_{298}^{\circ}$ value for berthierite (245.0 $\mathrm{J} \cdot \mathrm{mole}^{-1} \cdot \mathrm{K}^{-1}$; Dzhabbarov, 1985). The paucity of entropy data for sulfosalts precludes the development of a more rigorous estimation method. Skinner et al. (1972) determined an upper stability for chalcostibite of $826 \mathrm{~K}$. The recommended thermodynamic properties for chalcostibite are presented in Table 4. The calculated $\Delta_{f} \mathrm{G}_{298}^{\circ}$ for chalcostibite based on the expression of Craig and Barton (1973) is approximately $8 \mathrm{~kJ} \cdot \mathrm{mole}^{-1}$ less negative than the value from the present study.

Bryndzia and Kleppa (1988b) measured the enthalpy change associated with the reaction $1 / 2 \mathrm{Cu}_{2} \mathrm{~S}$ $+1 / 2 \mathrm{Sb}_{2} \mathrm{~S}_{3}=\mathrm{CuSbS}_{2}$, which can also be used to calculate the thermodynamic properties of chalcostibite. Their data can be combined with the $\Delta_{f} \mathrm{H}_{298}^{\circ}$ for

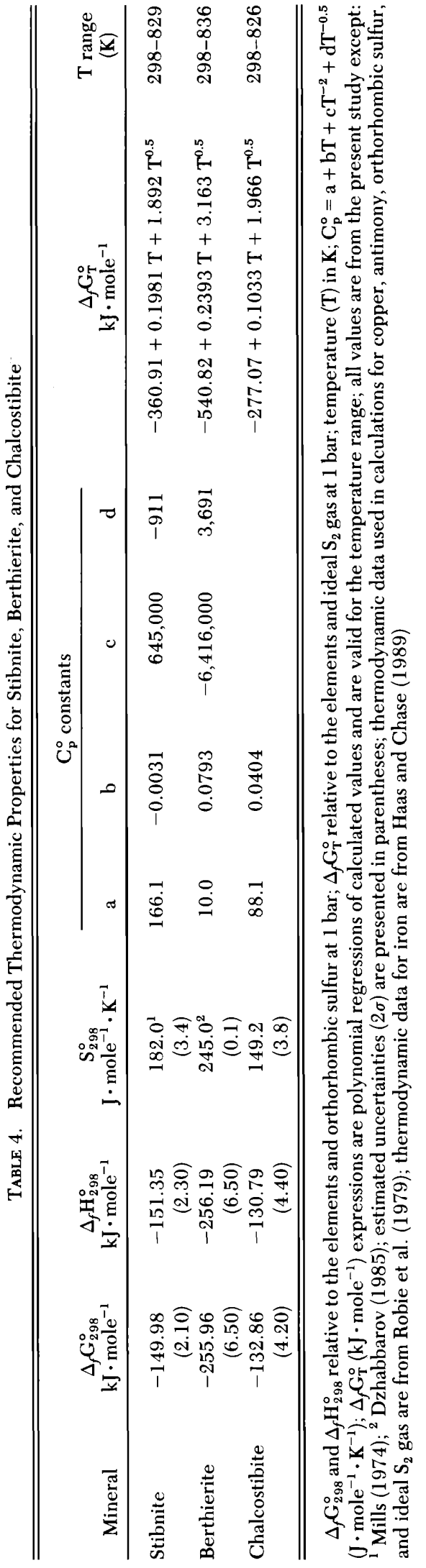




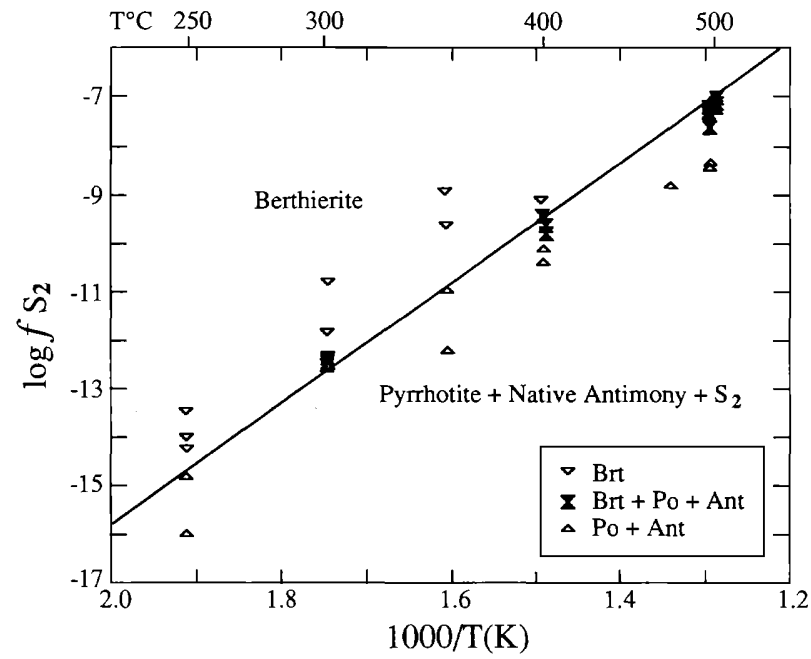

FIG. 3. Temperature- $f_{\mathrm{S}_{2}}$ diagram for reaction (3). The line represents the calculated curve from the present study. The activity of $\mathrm{FeS}$ in pyrrhotite used in the calculations was based on Toulmin and Barton (1964). Experimental data are from Barton (1971), Bortnikov et al. (1978), and Nekrasov and Konyushok (1982). The uncertainty in the experimental data is approximately $\pm 5^{\circ} \mathrm{C}$ and $\pm 0.35 \log f_{\mathrm{S}_{2}}$ units.

chalcocite $\left(-84.21 \mathrm{~kJ} \cdot\right.$ mole $\left.^{-1}\right)$, based on a "thirdlaw" evaluation (Robie, 1965) of the gas-mixing data of Brooks (1953), and the $\Delta_{f} \mathrm{H}_{298}^{\circ}$ for stibnite from the present study to calculate a $\Delta_{f} \mathbf{H}_{298}^{\circ}(-137.98$ $\left.\mathrm{kJ} \cdot \mathrm{mole}^{-1}\right)$ and $\mathrm{S}_{298}^{\circ}\left(138.5 \mathrm{~J} \cdot \mathrm{mole}^{-1} \cdot \mathrm{K}^{-1}\right)$ for chalcostibite. The calculated $S_{298}^{\circ}$ value represents a 7.2 percent deviation from the estimated value. The rea- son for this difference is not clear at present. Compared to values for other sulfides and sulfosalts discussed above, this amount of deviation from the sum of the component sulfides appears to be unprecedented. Therefore, the thermodynamic properties based on the estimated $\mathrm{S}_{298}^{\circ}$ are preferred.

\section{Phase Equilibria}

The revised thermodynamic properties may be used to unravel some of the uncertainties in the lowtemperature phase equilibria in the system $\mathrm{Fe}-\mathrm{Sb}-\mathrm{S}$, as noted by Barton (1971). Thermodynamic data for stibnite and berthierite are from the present study; data for gudmundite (FeSbS) and seinäjokite $\left(\mathrm{FeSb}_{2}\right)$ are from Barton (1970); and all other data are from Barton and Skinner (1979). Unit activities are assumed for all components corresponding to solid phases except for $\mathrm{FeS}$ in pyrrhotite, which was modeled using the expressions of Toulmin and Barton (1964). Due to the colinearity of FeS, FeSbS, and $\mathrm{Sb}$, the formula $\mathrm{Fe}_{1-\mathrm{x}} \mathrm{S}$ for pyrrhotite is necessary to describe accurately the stoichiometry of the products and reactants in reaction 7 . For all other reactions, the simpler formula FeS is sufficient. Reactions that limit the stability of berthierite are presented in Figures 4 and 5 . Below its melting point at $836 \mathrm{~K}$ $\left(563^{\circ} \mathrm{C}\right)$, the stability of berthierite is dominantly limited by reactions 2 and 3 . Its lower temperature stability occurs at the intersection of reaction 1 and the reaction

$$
\mathrm{FeS}_{2}+2 \mathrm{Sb}+\mathrm{S}_{2}=\mathrm{FeSb}_{2} \mathrm{~S}_{4}
$$

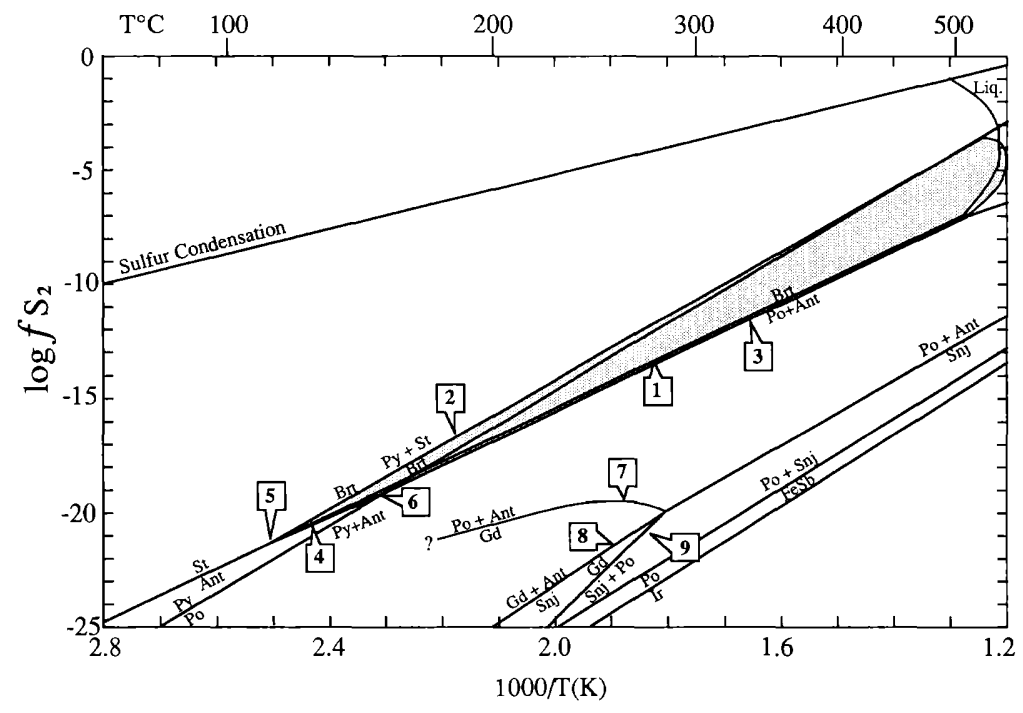

FIG. 4. Calculated phase equilibria in the system Fe-Sb-S. Shaded field represents the stability of berthierite. The numbers correspond to the reactions discussed in the text. Reactions 1 to 6 were calculated from the present study. All others are based on Barton (1971) and Barton and Skinner (1979). Abbreviations: berthierite (Brt); gudmundite (Gd); native antimony (Ant); native iron (Ir); pyrite (Py); pyrrhotite (Po); stibnite (St); seinäjokite $(\mathrm{Snj})$. 


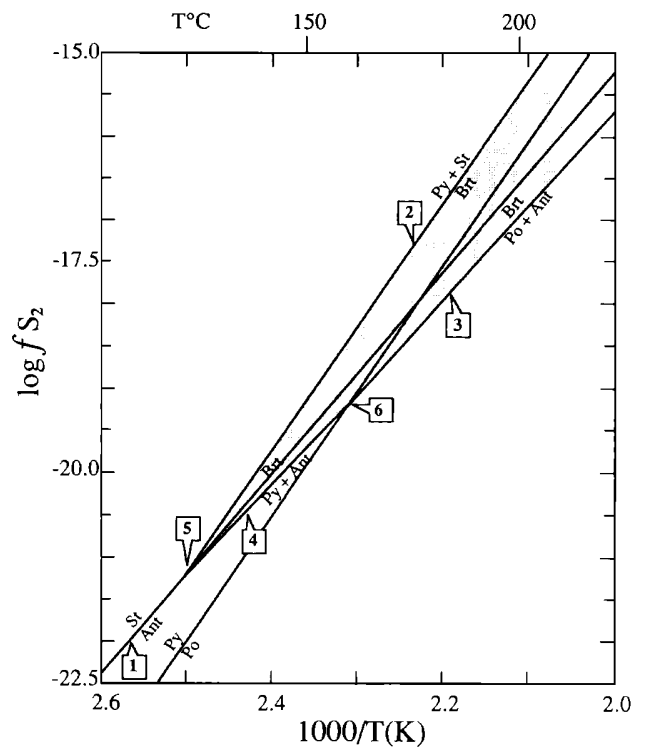

FiG. 5. Calculated phase equilibria in the system Fe-Sb-S for the low-temperature portion of Figure 4 . The numbers correspond to the reactions discussed in the text. Reactions 1 to 6 were calculated from the present study. All others are based on Barton (1971) and Barton and Skinner (1979). Abbreviations: berthierite (Brt); native antimony (Ant); pyrite (Py); pyrrhotite (Po); stibnite (St).

along the stibnite-native antimony curve at $398 \pm 30$ $\mathrm{K}\left(125^{\circ} \mathrm{C}\right)$ at the invariant point corresponding to the reaction

$\mathrm{FeS}_{2}+2 / 3 \mathrm{Sb}+2 / 3 \mathrm{Sb}_{2} \mathrm{~S}_{3}=\mathrm{FeSb}_{2} \mathrm{~S}_{4}$

(vapor present).

Reaction 4 has a restricted stability that is limited between 398 and $433 \pm 30 \mathrm{~K}\left(160^{\circ} \mathrm{C}\right)$, the invariant point corresponding to the reaction

$3 \mathrm{FeS}_{2}+2 \mathrm{Sb}=2 \mathrm{FeS}+\mathrm{FeSb}_{2} \mathrm{~S}_{4} \quad$ (vapor present).

Reactions that restrict the stability of gudmundite and seinäjokjite have also been calculated and include:

$$
\begin{gathered}
(1-\mathrm{x}) \mathrm{FeSbS}+\mathrm{x} / 2 \mathrm{~S}_{2}=\mathrm{Fe}_{1-\mathrm{x}} \mathrm{S}+(1-\mathrm{x}) \mathrm{Sb} . \\
\mathrm{FeSbS}+\mathrm{Sb}=\mathrm{FeSb}_{2}+1 / 2 \mathrm{~S}_{2} .
\end{gathered}
$$

and

$$
2 \mathrm{FeSbS}=\mathrm{FeSb}_{2}+\mathrm{FeS}+1 / 2 \mathrm{~S}_{2} .
$$

These reactions merge at $553 \mathrm{~K}\left(280^{\circ} \mathrm{C}\right)$, the thermal maximum for gudmundite (Clark, 1966). The position of reaction 7 at lower temperatures is difficult to assess because of the large uncertainty in the thermal dependence of the Gibbs free energy of gudmundite.
The present study has provided insight into many of the uncertainties in the low-temperature $(<673$ $\mathrm{K}$ ) phase equilibria in the system $\mathrm{Fe}-\mathrm{Sb}-\mathrm{S}$ as noted by Barton (1971). However, numerous questions still remain. The large uncertainties in temperatures calculated for the invariant points that limit the stability of berthierite can be decreased by improvements in the thermodynamic data for associated phases or by direct, experimental determination of the invariant points. Unfortunately, such experimental efforts must contend with the formidable kinetic barriers imposed by these low temperatures. Uncertainties in the low-temperature phase relations involving gudmundite can most easily be diminished by obtaining heat capacity data for this mineral.

\section{Acknowledgments}

This research was supported by a National Research Council Postdoctoral Associateship. J. Jackson and $\mathrm{H}$. T. Haselton assisted with the X-ray diffraction studies. The manuscript benefited from reviews by H. T. Haselton, G. R. Robinson, Jr., and an Economic Geology reviewer.

April 29, June 23, 1992

\section{REFERENCES}

Barton, P. B., Jr., 1970, Sulfide petrology: Mineralog. Soc. America Spec. Paper 3, p. 187-198.

- 1971, The Fe-Sb-S system: ECON. GEOL., v. 66, p. 121-132. Barton, P. B., Jr., and Skinner, B. J., 1979, Sulfide mineral stabilities, in Barnes, H. L., ed., Geochemistry of hydrothermal ore deposits: New York, Wiley Intersci., p. 278-403.

Bayliss, P., and Nowacki, W., 1972, Refinement of the crystal structure of stibnite, $\mathrm{Sb}_{2} \mathrm{~S}_{3}$ : Zeitschr. Kristallographie, v. 135, p. 308-315.

Bortnikov, N. S., Nekrasov, I. Y., and Mozgova, N. N., 1978, Phase ratios in the system $\mathrm{Fe}-\mathrm{Pb}-\mathrm{Sb}-\mathrm{S}$ at $400^{\circ}$ to $500^{\circ} \mathrm{C}$ : Akad. Nauk SSSR Doklady, v. 239, p. 420-423.

Britzke, E. V., and Kapustinskii, A. F., 1930, Die Affinitat von Metallen zu Schwefel: Zeitschr. Anorg. Allg. Chemie, v. 194, p. 323-350.

Brooks, A. A., 1953, A thermodynamic study of the equilibrium $2 \mathrm{Cu}(\mathrm{s})+\mathrm{H}_{2} \mathrm{~S}(\mathrm{~g})=\mathrm{Cu}_{2} \mathrm{~S}(\gamma)+\mathrm{H}_{2}(\mathrm{~g}):$ Am. Chem. Soc. Jour., $\mathrm{v}$. 75 , p. $2464-2467$.

Bryndzia, L. T., and Kleppa, O. J., 1988a, High-temperature reaction calorimetry of solid and liquid phases in the quasi-binary system $\mathrm{Ag}_{2} \mathrm{~S}-\mathrm{Sb}_{2} \mathrm{~S}_{3}$ : Geochim. et Cosmochim. Acta, v. 52, p. $167-176$

- 1988b, High-temperature reaction calorimetry of solid and liquid phases in part of the quasi-binary system $\mathrm{Cu}_{2} \mathrm{~S}-\mathrm{Sb}_{2} \mathrm{~S}_{3}$ : Am. Mineralogist, v. 73, p. 707-713.

Buerger, M. J., and Hahn, T., 1955, The crystal structure of berthierite, $\mathrm{FeSb}_{2} \mathrm{~S}_{4}$ : Am. Mineralogist, v. 40, p. 226-238.

Clark, A. H., 1966, Heating experiments on gudmundite: Mineralog. Mag., v. 35, p. 1123-1125.

Craig, J. R., and Barton, P. B., Jr., 1973, Thermochemical approximations for sulfosalts: ECON. GEOL., v. 68, p. 493-506.

Craig, J. R., and Lees, W. R., 1972, Thermochemical data for sulfosalt ore minerals: Formation from simple sulfides: ECON. GEOL., v. 67 , p. $373-377$.

Dzhabbarov, A. I., 1985, Heat capacity of the anisotropic antiferromagnetic semiconductor iron antimony sulfide $\left(\mathrm{FeSb}_{2} \mathrm{~S}_{4}\right)$ 
at low temperatures: Zhur. Fizicheskoi Khimii, v. 59, p. 202204.

Grønvold, F., and Westrum, E. F., 1987, Thermodynamics of copper sulfides I. Heat capacity and thermodynamic properties of copper (I) sulfide, $\mathrm{Cu}_{2} \mathrm{~S}$, from 5 to $950 \mathrm{~K}$ : Jour. Chem. Thermodynamics, v. 19, p. 1183-1198.

Gurevich, V. M., Gorbunov, V. E., Gavrichev, K. S., and Khodakovsky, I. L., 1989, Low-temperature heat capacity of proustite $\mathrm{Ag}_{3} \mathrm{AsS}_{3}$ and smithite $\mathrm{AgAsS}_{2}$ : Geokhimiya, p. 132-139.

Haas, J. L., Jr., and Chase, M. W., Jr., 1989, Thermodynamic data for iron from 200 to $3000 \mathrm{~K}$ and from 0 to $200 \mathrm{kbar}$ U. S. Geol. Survey Open-File Rept. 89-138, 156 p.

Haas, J. L., Jr., and Fisher, J. R., 1976, Simultaneous evaluation and correlation of thermodynamic data: Am. Jour. Sci., v. 276, p. $525-545$.

Hemingway, B. S., Krupka, K. M., and Robie, R. A., 1981, Heat capacities of the alkali feldspars between 350 and $1000 \mathrm{~K}$ from differential scanning calorimetry, the thermodynamic functions of the alkali feldspars from 298.15 to $1400 \mathrm{~K}$, and the reaction quartz + jadeite $=$ analbite: Am. Mineralogist, v. 66 , p. $1202-$ 1215 .

Hofman, W., 1933, Strukturelle und morphologische zusammenhange bei erzen vom formeltyp $\mathrm{ABC}_{2}$. I. Die struktur von wolfsbergit $\mathrm{CuSbS}_{2}$ und emplektit $\mathrm{CuBiS}_{2}$ und beren beziehungen zu der struktur von antimonit $\mathrm{Sb}_{2} \mathrm{~S}_{3}$ : Zeitschr. Kristallographie, v. 84, p. $177-203$.

Jellinek, K., and Zakowski, J., 1925, Uber die Affinitat der Metalle zum Schwefel: Zeitschr. Anorg. Allg. Chemie, v. 142, p., 1-53.

Johnson, G. K., Papatheodorou, G. N., and Johnson, C. E., 1981, The enthalpies of formation of $\mathrm{SbF}_{5}(\mathrm{l})$ and $\mathrm{Sb}_{2} \mathrm{~S}_{3}(\mathrm{c})$ and hightemperature thermodynamic functions of $\mathrm{Sb}_{2} \mathrm{~S}_{3}(\mathrm{c})$ and $\mathrm{Sb}_{2} \mathrm{~S}_{3}(1)$ : Jour. Chem. Thermodynamics, v. 13, p. 745-754.

Kelley, K. K., 1937, Contributions to the data on theoretical metallurgy. VII. The thermodynamic properties of sulfur and its inorganic compounds: U. S. Bur. Mines Bull. 406, 154 p.

King, E. G., and Weller, W. W., 1962, Low-temperature heat capacities and entropies at $298.15 \mathrm{~K}$ of antimony and indium sulfides: U. S. Bur. Mines Rept. Inv. 6040, 5 p.

Mills, K. C., 1974, Thermodynamic data for inorganic sulfides, selenides and tellurides: London, Butterworths.

Nekrasov, I. Y., and Konyushok, A. A., 1982, Sistema Au-Fe-Sb-S v gidrotermal'nykh usloviyakh pri $300-600^{\circ} \mathrm{C}$ : Akad. Nauk SSSR Doklady, v. 265 , p. $180-185$.

Pelabon, H., 1902, Action de l'hydrogene sur les sulfures et seleniures: Annales Chimie et Physique, v. 25, p. 365-431.

Robie, R. A., 1965, Heat and free energy of formation of herzenbergite, troilite, magnesite, and rhodocrosite calculated from equilibrium data: U.S. Geol. Survey Prof. Paper 525D, p. 6572

Robie, R. A., Hemingway, B. S., and Fisher, J. R., 1979, Thermodynamic properties of minerals and related substances at $298.15 \mathrm{~K}$ and 1 bar $\left(10^{5}\right.$ Pascals $)$ pressure and at higher temperatures: U. S. Geol. Survey Bull. 1452, 456 p.

Robie, R. A., Wiggins, L. B., Barton, P. B., Jr., and Hemingway, B. S., 1985, Low-temperature heat capacity and entropy of chalcopyrite $\left(\mathrm{CuFeS}_{2}\right)$ : Estimates of the standard molar enthalpy and Gibbs free energy of formation of chalcopyrite and bornite $\left(\mathrm{Cu}_{5} \mathrm{FeS}_{4}\right)$ : Jour. Chem. Thermodynamics, v. 17, p. 481-488.

Romanovskii, V. A., and Tarasov, V. V., 1960, Heat capacity of the trisulfides of arsenic, antimony, and bismuth in connection with their structural and physical-chemical properties: Soviet Physics-Solid State, v. 2, p. 1170-1175.

Schenck, R., and von der Forst, P., 1939, Gleichewichtsstudien an erzbildenden sulfiden II: Zeitschr. Anorg. Allg. Chemie, v. 241 , p. 145-157.

Schenck, R., Hoffman, I., Knepper, W., and Volger, H., 1939, Gleichewichtsstudien uber erzbildende sulfide: Zeitschr. Anorg. Allg. Chemie, v. 240, p. 178-197.

Seal, R. R., II, Essene, E. J., and Kelly, W. C., 1990, Tetrahedrite and tennantite: Evaluation of thermodynamic data and phase equilibria: Canadian Mineralogist, v. 28, p. 725-738

Skinner, B. J., Luce, F. D., and Makovicky, E., 1972, Studies of the sulfosalts of copper. III. Phases and phase relations in the system Cu-Sb-S: ECON. GEOL., v. 67, p. 924-938.

Sudo, K., 1952, Smelting of sulfide ores XIII, the equilibrium in the reduction of solid antimony trisulfide by hydrogen: Tohoku Univ., Research Inst. Mineral Dressing Metallurgy Bull., v. 8, p. $117-122$.

Toulmin, P., III, and Barton, P. B., Jr., 1964, A thermodynamic study of pyrite and pyrrhotite: Geochim. et Cosmochim. Acta, v. 28 , p. 641-67l. 